\title{
Design of a Monitoring System for Hydroganics based on Arduino Uno R3 to Realize Sustainable Development Goal's number 2 Zero Hunger
}

\author{
Anggara Trisna Nugraha ${ }^{1}$, and Dadang Priyambodo \\ Marine Electrical Engineering Shipbuilding Institute of Polytechnic Surabaya, Surabaya, Jl. Teknik Kimia Keputih Sukolilo, Surabaya 60111, Indonesia. \\ Corresponding Author: anggara Trisna Nugraha, (anggaranugraha@ppns.ac.id)
}

ABSTRACT In 2019 Indonesia is able to support its nation and does not need rice imports from abroad. This situation is called rice self-sufficiency. Then in order to maintain rice self-sufficiency from year to year, it is necessary to apply technology to increase the quality of rice production. Therefore, a Hydroganic Monitoring System Design was created which is used to monitor plant watering automatically using the YL69 soil moisture sensor controlled by Arduino Uno and instructed to the LCD to display the soil moisture value according to soil $\mathrm{pH}$ in real time. The watering system that has been created can automatically drain water to the plants. The water that is flowed automatically by this system comes from the fish pond that is right below it, where the water from fish excrement will produce organic nutrients for rice plants. With this research, rice production will grow more effectively to improve rice quality. With this research, it is expected that Indonesian rice production will increase effectively and in line with the improvement of rice quality. From the research that has been conducted, it is found that from the experimental data above, it can be calculated that the average water discharge in one irrigation is $2.37 \mathrm{~m} / \mathrm{s}$.

INDEXT TERM: Hydroganic, Monitoring System, Soil moisture, Organic Filtration

\section{INTRODUCTION}

Indonesia is a large agricultural country, and most of the population of this country lives from agriculture [1]. Over time, the population of Indonesia is increasing and will reach 267 million by 2019 [2]. Because of these problems, people who are aware of this are more active in developing the agricultural sector [3]. It can be seen in the New Order era, Indonesian agriculture again achieved rice self-sufficiency in 2019 [4] - [5]. On the other hand, the population in 1984 reached 164 million and needed 27 million tons of rice every year, while in 2019 the population reached 267 million and needed 32.4 million tons of rice every year. Rice production in 1984 only reached 25.8 million tons, while rice production in 2019 reached 34.9 million tons per year [6] - [7]. In this regard, it is clear that Indonesia will no longer need to import rice from abroad in 2019 and this situation is called rice self-sufficiency. So in order to maintain rice self-sufficiency from year to year, it is necessary to apply technology to increase the quality of rice production [8].

If maintained, rice self-sufficiency itself will make Indonesia a country that can meet the country's food needs independently and globally by acting as a supplier. To support this, an innovation is needed so that rice yields continue to increase. To support this orientation, it is necessary to develop technology to simplify and optimize rice farming through the creation of a tool in the form of a Monitoring System Design for Hydroganics. This research was conducted by monitoring plant watering automatically using a soil moisture sensor YL-69 which is controlled by an automatic pump and instructed to the LCD to display the soil moisture value according to the realtime soil $\mathrm{pH}$. Plant watering systems that have been made can drain water to plants automatically [9]. Then, the LCD will receive and display the value of the ground conditions. When the soil conditions of the rice plant are dry, the sensor will be sensitive and the water will flow automatically which is assisted by a pump that comes from the fish pond right below it. This water contains organic substances which are useful as organic fertilizers for rice plants. With this research, it is expected that Indonesian rice production will increase effectively and in line with the increase in rice quality [10].

\section{MATERIALS AND METHODS}

This chapter will introduce some literature reviews or brief references. 


\section{A. TOOLS AND MATERIALS}

Soil moisture plays an important role in irrigation and botanical gardens. Because the nutrients in the soil provide food for plant growth. The water supply to plants is also important for changing plant temperatures. Plant temperature can be changed with water through transpiration and other methods. When grown in moist soil, the plant's root system will develop better. Extreme soil moisture can lead to anaerobic conditions, thus encouraging the growth of plants and pathogens in the soil. This article discusses the general situation, working principles and applications of soil moisture sensors [11].

Soil moisture sensor is a sensor to measure the amount of water in the soil. The direct weight dimension of soil moisture needs to be removed, dried and weighed. The sensor does not directly rely on some other basic rules (such as dielectric constant, resistance, reverse interaction with neutrons, and moisture substitution) to measure volumetric moisture content.

Arduino is an open source electronics platform based on easy-to-use hardware and software. The Arduino development board can read input lights on sensors, fingers on buttons or Twitter messages - and turn them into output-driven motors, power LEDs, and post content online. You can tell you what to do by sending a set of instructions to the microcontroller on the board. For this, you use the processing-based Arduino programming language (Wiring-based) and the Arduino (IDE) software [12].

Over the years, Arduino has been the brains of thousands of projects, from everyday objects to complex scientific instruments. On this open source platform, a global community of students, amateurs, artists, programmers and professionals converge on this open source platform. Their contribution has accumulated unmatched accessibility knowledge, which is very useful for beginners, and experts can be of great help.

Arduino was born at Ivrea Interactive Design Institute. It is a simple tool for rapid prototyping, especially for students without a background in electronics and programming. Once the Arduino development board entered the wider community, it began making changes to adapt to new needs and challenges, expanding its products from simple 8-bit development boards to IoT applications, wearables, 3D printing, and embedded environmental products. All Arduino development boards are completely open source, allowing users to build them independently and eventually adapt them to specific needs. The software is also open source and will continue to be developed with contributions from users around the world [13].

The Ministry of Health recommends two barrier methods filtration and disinfection. While we can provide a variety of solutions to meet your needs, the simplest solution is filter cartridge filtering and then UV disinfection [14]. Filtration is based on the micron level and is usually achieved by coarse prefiltration, typically using a washable 20 micron pleated filter cartridge to remove most of the suspended solids, and then filtering 1 micron. This step is the most important for capturing Giardia and Cryptosporidium cysts in the filter [15].
It is disinfected by exposure to ultraviolet light. This can deactivate bacterial and viral contaminants. The micro lens system is designed to provide constant water pressure based on the available flow. Another alternative but less popular method of disinfection involves the use of an oxidizing chemical, such as Acquasafe (note - this will not kill Giardia and Cryptosporidium cysts).

Another option in water treatment processes is to remove dissolved substances and gases that affect taste and smell. Activated carbon is a medium that can remove chlorine and its by-products, pesticides, and sulfur. Usually, only this filter is selected for drinking water treatment. Some can get rid of Giardia cysts, and some are insecticides with taste and smell. However, they will not eliminate bacteria and viruses.

Water pumps and dehydration systems are water treatment equipment that uses the pumping or evaporation method to remove or discharge various forms of water from construction sites, riverbeds, mines, subway networks, tunnels, caissons and even residential buildings. In many places, these systems are essential for monsoons, rainstorms, or flood areas, as groundwater and rainwater can flood entire sites in just a few hours, causing delays, surface erosion, structural damage and downtime.

There are several types of water pumps, including positive displacement pumps, centrifugal pumps, jet pumps and submersible pumps. Some systems have been installed as longterm solutions that can work continuously and take immediate action at any time, while other systems are typically used immediately or in short or short term use (as equipment or service leases) after water seepage or damage.

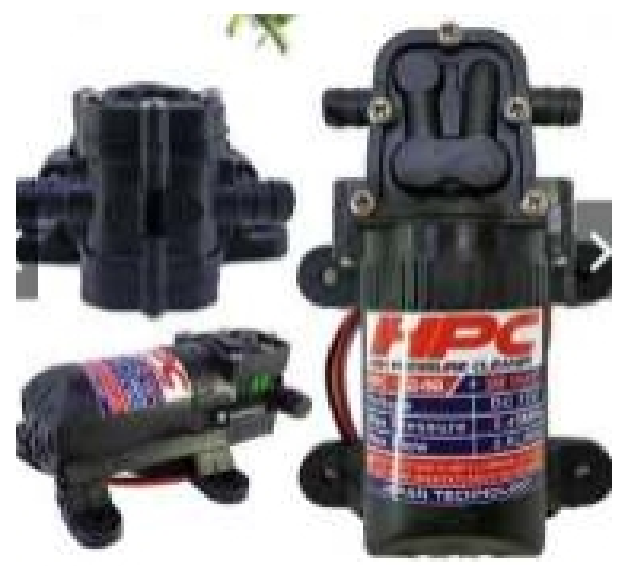

Fig. 1. DC 12V Water Pump

The H-bridge is a circuit that can drive current of any polarity and is controlled by pulse width modulation (PWM). Pulse width modulation is a method for controlling the duration of electronic pulses. In the car, the brush is considered a water wheel, and the electrons are considered as flowing water droplets. The water tension will flow through the wheels at a constant speed, the more water flowing, the higher the tension. The rated voltage of the motor is a certain specific voltage, if the applied voltage is too high or the voltage drops too fast, the 
motor will slow down and damage the motor. Because of this, PWM. Suppose there is a water wheel and imagine water hitting water with a constant current. The longer the pulse time, the faster the waterwheel rotates, and the shorter the pulse, the slower the waterwheel rotates. If controlled by PWM, the motor will be more durable and reliable. The DC $12 \mathrm{~V}$ water pump can provide a strong spraying capacity, which is especially useful if it is used for daily household chores (such as cleaning cars, watering plants in a garden, or other purposes that require water spraying).

The conclusion is that this sensor is suitable for NodeMCU and Arduino, because it can work on logic from $3.3 \mathrm{~V}$ to $5 \mathrm{~V}$. The unique features of this sensor are its adjustable sensitivity and a blue digital potentiometer. The PCB board size used is $3 \times 1.6$ $\mathrm{cm}$, with a power indicator (red) and a green digital output indicator. The bolt holes applied to this sensor are fixed and easy to install.

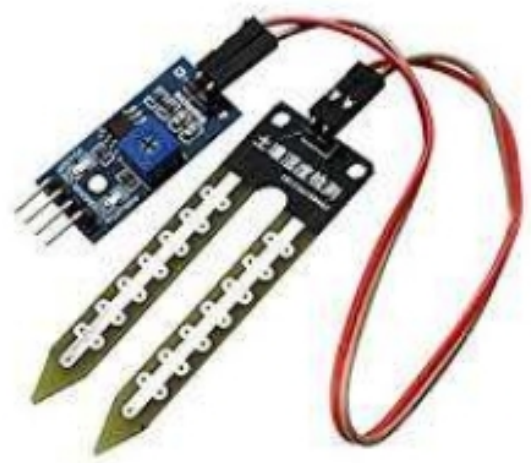

Fig. 2. Soil Moisture Sensor YL-69

\section{B. SIMPLE ORGANIC FILTRATION SYSTEM}

Water purification is the process of supplying water for a specific purpose. For example water is used for drinking water, industrial processes, medical care, agriculture, etc. These uses are of a different standard or quality.

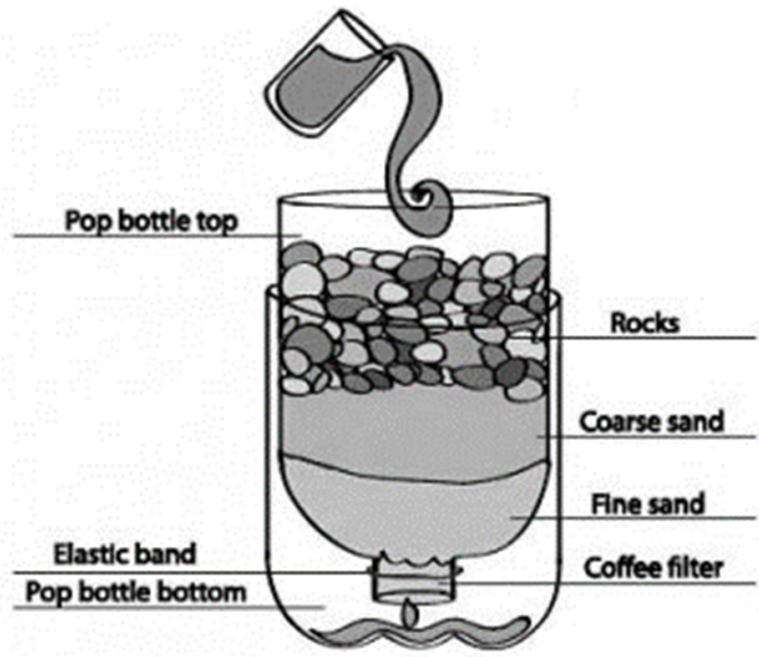

Fig. 3. Filtration
Filtration is the process of separating a solid from a liquid or gas using a filter media that allows the liquid to pass but not the solid. The term "filtration" applies regardless of whether the filter is mechanical, biological, or physical. The liquid that passes through the filter is called the filtrate. The filter media can be in the form of surface filters which are solids to capture solid particles, or in the form of depth filters which are the basic materials for trapping solids.

Filtration is usually an imperfect process. Some of the liquid remains on the feed side of the filter or is embedded in the filter media, while some small solid particles pass through the filter. As a chemical and engineering technology, certain products (both liquid and solid) will be lost forever.

\section{MECHANICAL DESIGN}

The design here has a model function and a reference function in the form of installation and performance design. Mechanical design or mechanical design is one of the important branches of engineering design. In order to understand what is mechanical design or mechanical design, let us consider an example of a car gearbox. The gearbox transmits engine movement and power to the wheels of the vehicle. The gearbox includes a set of gears that not only support movement, but also support the load of the vehicle. In order for the gears to work at the required speed and withstand the required loads, it is very important to design these gears. In the design process, the required speed and load must be considered, then various calculations must be carried out, and finally a certain material and a certain gear size are designed. The gears can withstand all loads and can achieve the best performance at the lowest cost. All auto parts are the same. The product design (including machines) must meet all functional requirements at the lowest cost. The entire design process is called machine design or mechanical design.

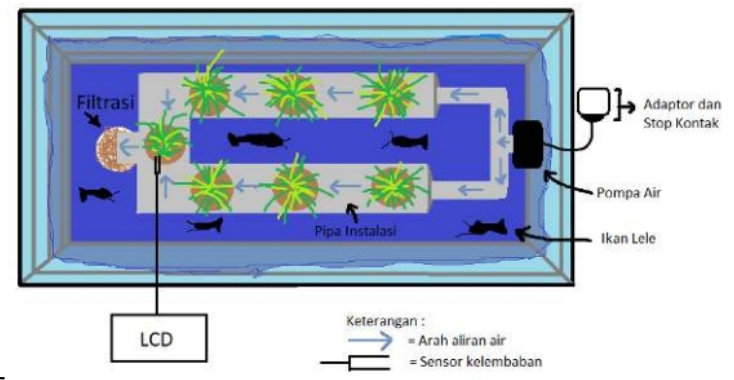

Fig. 4. Mechanical Design

\section{FLOWCHART}

The image above shows that soil moisture is the initial key to the activity of this organic hydrogen monitoring system. If the soil moisture has reached the minimum limit which triggers the active response of the soil moisture sensor, the LCD will display the current soil moisture value. In addition, the pump will run automatically. 


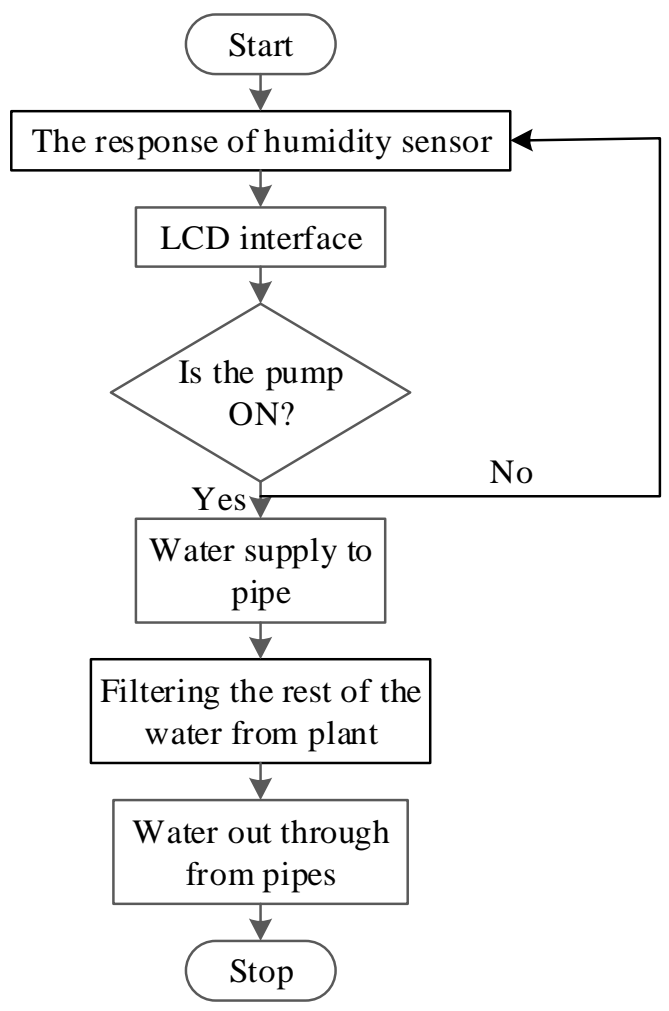

Fig. 5. Flowchart

\section{RESULTS}

\section{A. SOIL MOISTURE MEASUREMENT.}

This experiment was carried out in order to determine the value of soil moisture used as a stimulus value for soil water sensore. By using a temperature that affects the evaporation of nutrients in the plant, then this is directly proportional to the humidity value later, which will later be able to activate the pump which will automatically flow the plants when the humidity of the planting medium.

TABLE I

TESTING DATA OF HUMIDITY HYDRAULIC INSTALLATIONS

\begin{tabular}{cccc}
\hline No & Time & Temperature $\left({ }^{\circ} \mathrm{C}\right)$ & Humidity (\%) \\
\hline 1 & 12.00 & 31 & 74 \\
\hline 2 & 03.00 & 33 & 88 \\
\hline 3 & 06.00 & 30 & 65 \\
\hline 4 & 09.00 & 32 & 75 \\
\hline
\end{tabular}

From the tests that have been done, a graph can be made as shown below.

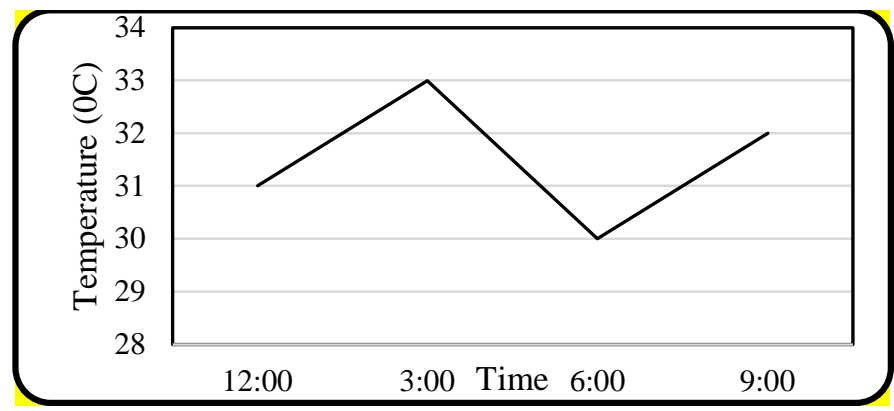

Fig. 6. Temperature measurement

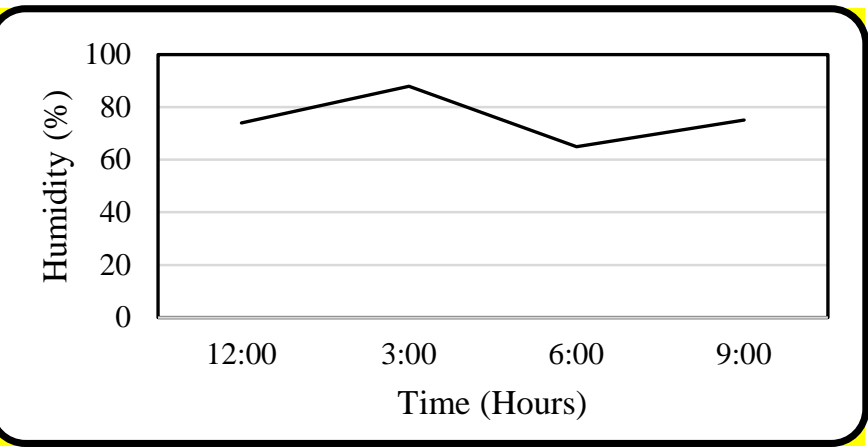

Fig. 7. Humidity Measurement

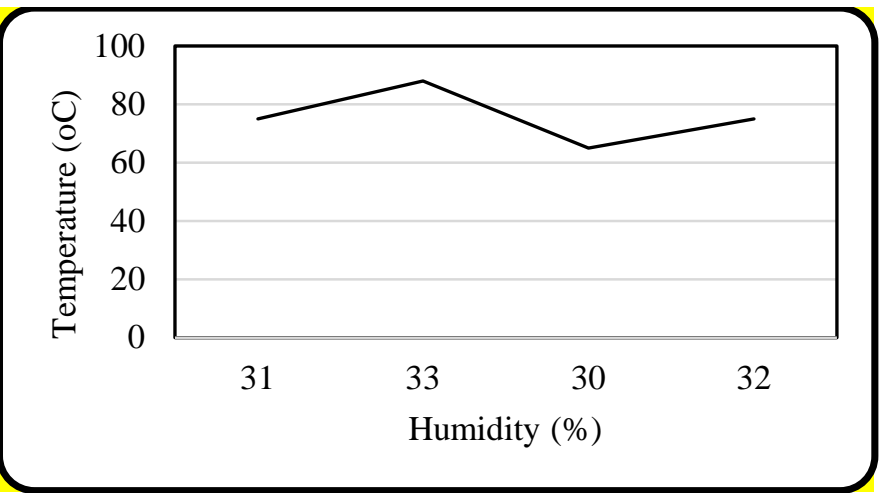

Fig. 8. Temperature vs Humidity Test

\section{B. TIME MEASUREMENT}

Measuring the Time Needed for Once Irrigation. the water flow required by the pump for one time irrigation. This is needed to optimize the air flow so that the plant gets an appropriate air supply.

TABLE II. TESTING DATA OF WATERING TIME FOR CORN PLANTS IN HYDROGANIC INSTALLATIONS.

\begin{tabular}{ccc}
\hline No & Trial & Time required \\
\hline 1 & Trial 1 & 07.52 Minute \\
\hline 2 & Trial 2 & 09.14 Minute \\
\hline 3 & Trial 3 & 08.22 Minute \\
\hline
\end{tabular}


From the tests that have been done, a graph can be made as shown below.

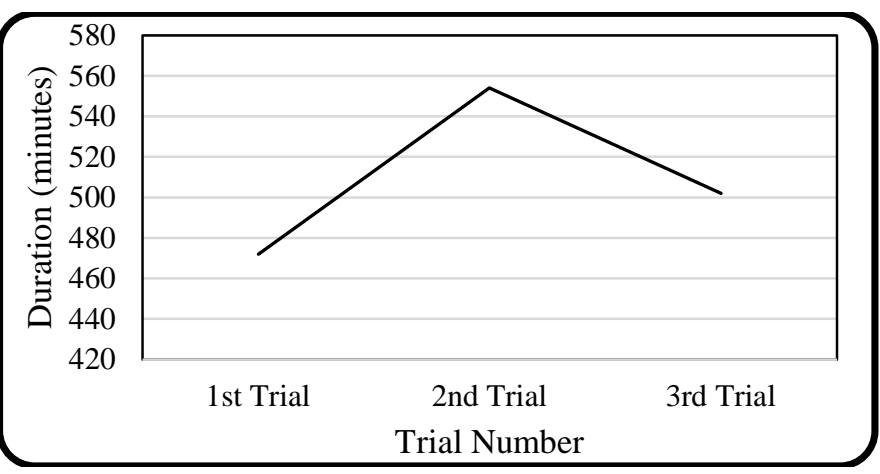

Fig. 9. Irrigation`s Time

\section{MEASUREMENT OF WATER DISCHARGE PER UNIT TIME FOR ONE TIME IRRIGATION.}

This experiment was carried out with the aim of seeing the large water discharge in the pipe installation. It is ready to determine if the watering time is appropriate.

TABLE III.

TESTING DATA OF RICE PLANT WATER DEBIT IN HYDROGANIC INSTALLATIONS

\begin{tabular}{ccccc}
\hline No & Trial & $\begin{array}{c}\text { Volume } \\
\text { Water } \\
\text { flow }\end{array}$ & $\begin{array}{c}\text { Cross- } \\
\text { sectional } \\
\text { area }\end{array}$ & $\begin{array}{c}\text { Water } \\
\text { Discharge }\end{array}$ \\
\hline 1 & Trial 1 & 1.51 & $8,636 \mathrm{Cm}$ & $2,8 \mathrm{~m}^{3} / \mathrm{s}$ \\
\hline 2 & Trial 2 & 1.51 & $8,636 \mathrm{Cm}$ & $3,07 \mathrm{~m}^{3} / \mathrm{s}$ \\
\hline 3 & Trial 3 & 1.51 & $8,636 \mathrm{Cm}$ & $1,84 \mathrm{~m}^{3} / \mathrm{s}$ \\
\hline
\end{tabular}

From the tests that have been done, a graph can be made as shown below.

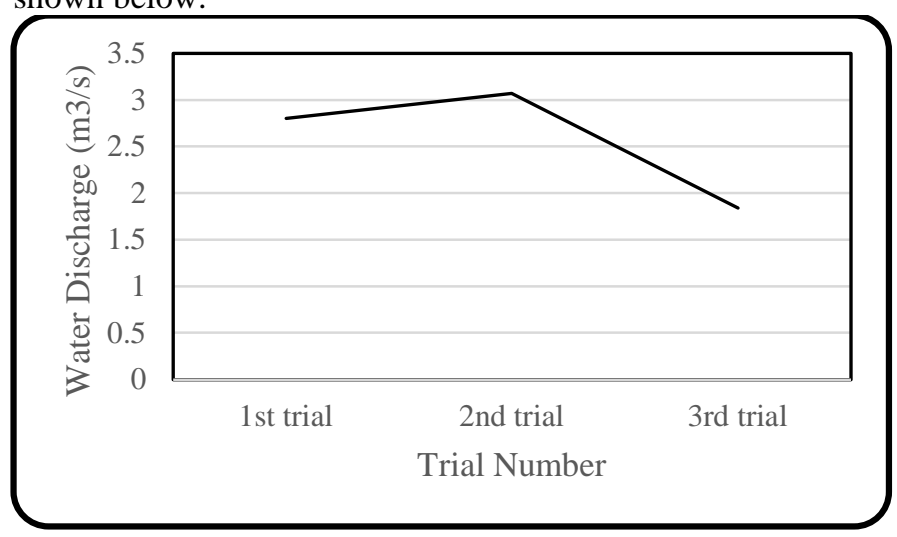

Fig. 10. Water Discharge

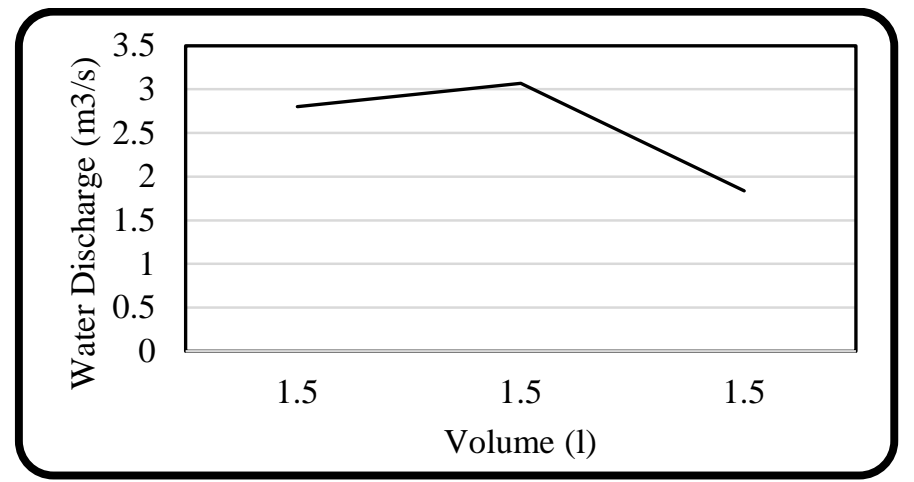

Fig. 11. Corelation between water discharge and volume

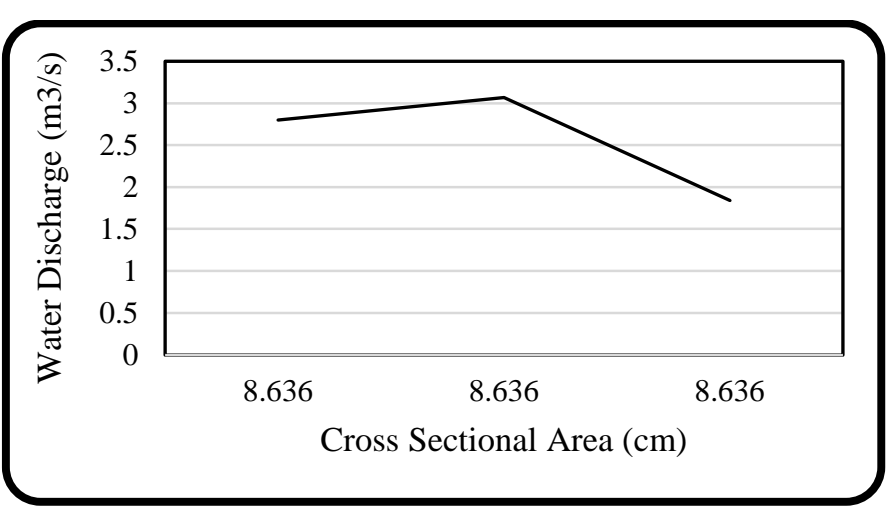

Fig. 12. Corelation between water discharge and cross sectional area

From the experimental data above, it can be calculated that the average water discharge in one irrigation is $2.37 \mathrm{~m} / \mathrm{s}$.

\section{DISCUSSION}

Due to pollution, water filtration has become a necessity in most parts of the world. We have advanced technology to filter water, but natural selection has been around for hundreds of years, after which artificial alternatives emerged. Sand: Since 2000, sand has been used for water filtration. The Greeks and Romans used sand to remove sediment from ponds and bath water. Sand can filter particles as small as 25 microns. When eaten, oysters naturally filter out toxins. The water that passes through the oyster is purified enough to drink. In some parts of the world, natural oyster reefs are still the preferred method of water filtration. Adult oysters can filter more than 60 gallons of water per day. Plants are a natural choice for water filtration, especially in wetland areas [16]. Plants automatically filter household water by adding oxygen and removing carbon dioxide. Some plants also remove heavy metals and toxins, while stimulating the growth of beneficial bacteria. Lettuce and water hyacinth are so effective that they are sometimes included in the first step of purifying wastewater. Charcoal is a slow but effective water filter. The carbon in charcoal helps flush out toxins. Charcoal can filter particles below 1 micron, including nitrogen oxides, lead and sulfur oxides. If you use charcoal at home, make sure to buy hardwood charcoal and wash it thoroughly before purifying the water. Dirty or soft charcoal readily dissolves in water and is not purified [17]. 
Coconut filters water by absorbing water through its fiber layers. The purity of coconut milk is second only to water. Commercial water filters usually use coconut carbon filters to remove toxins and particles. Coconut coir, whether for commercial use or a self-filtering system, Can play the best role of particles, toxins and parasites (including Cryptosporidium and Giardia) [18]. In this research, soil moisture sensor YL-69 is used to monitor plant humidity automatically, which is controlled by an automatic pump. The LCD screen displays the soil moisture value in real time according to the soil $\mathrm{pH}$ value. The plant watering system that is created can automatically drain water to the plants. Then the LCD will receive and display the ground state value. When the soil conditions for rice plants are dry, the sensor becomes sensitive because of the pump in the fish pond below, and the water will flow automatically. The water contains organic matter and can be used as organic fertilizer for rice plants. Through this research, it is hoped that by increasing the quality of rice, rice production in Indonesia can be increased effectively. It can be seen from the research results that according to experimental data above the average drainage of one irrigation can be calculated as $2.37 \mathrm{~m} / \mathrm{s}$.

\section{CONCLUSION}

Filtration plays an important role in the water treatment process. It is a process of separating solid particles from liquid particles. This can be done through a complex process using a variety of machines or tools, but it can also be done in a simple manner with the same advantages. Through our experiments we understand the importance of filtering. Filtration can not only remove solid particles, but also prevent water clogging caused by solid particles, thereby contributing to the efficiency of the overall water treatment process. If there is no filtration solid particles can block other processes, making operation impossible. Soil moisture greatly affects the growth of rice plants, because rice is basically a plant that requires more nutrients. With the soil moisture sensor, soil moisture can be controlled automatically based on Arduino uno. Minimum soil moisture that is good for growing rice plants is around $58 \%$ $60 \%$. The appropriate time to flow $2,3 \mathrm{~J} 7 \mathrm{~m} 3$ / s of water is 4.42 minutes. The higher the temperature and sunlight intensity, the more often the sensor, pump and LCD will work every day.

\section{REFERENCES}

[1] Martin, Michael, Sofia Poulikidou, and Elvira Molin. "Exploring the environmental performance of urban symbiosis for vertical hydroponic farming." Sustainability 11, no. 23 (2019): 6724.

[2] Martin, Michael, and Elvira Molin. "Environmental assessment of an urban vertical hydroponic farming system in Sweden." Sustainability 11 , no. 15 (2019): 4124.DeLuca, Carlo J., et al. 2021. "Biosignal monitoring system and method." U.S. Patent No. 6,238,338.

[3] R. A. AT Nugraha. 2020. "Water Purification Technology Implementation Design," JEEMECS (Journal of Electrical Engineering, Mechatronic and Computer Science). 2(3). 1-2

[4] Sharma, Nisha, Somen Acharya, Kausal Kumar, Narendra Singh, and O. P. Chaurasia. "Hydroponics as an advanced technique for vegetable production: An overview." Journal of Soil and Water Conservation 17, no. 4 (2018): 364-371..

[5] Tocquin, Pierre, Laurent Corbesier, Andrée Havelange, Alexandra Pieltain, Emile Kurtem, Georges Bernier, and Claire Périlleux. "A novel high efficiency, low maintenance, hydroponic system for synchronous growth and flowering of Arabidopsis thaliana." BMC plant biology 3, no. 1 (2003): 1-10.

[6] R. A. AT Nugraha. 2020. "Gas Pressure Measurement On Rocket Chamber Based On Strain Gauge Sensor," JEEMECS (Journal of Electrical Engineering, Mechatronic and Computer Science). 2(3). 1-3.

[7] Sarooshi, Ruhi A., and G. C. Cresswell. "Effects of hydroponic solution composition, electrical conductivity and plant spacing on yield and quality of strawberries." Australian Journal of Experimental Agriculture 34, no. 4 (1994): 529-535.

[8] Crisnapati, Padma Nyoman, I. Nyoman Kusuma Wardana, I. Komang Agus Ady Aryanto, and Agus Hermawan. "Hommons: Hydroponic management and monitoring system for an IOT based NFT farm using web technology." In 2017 5th International Conference on Cyber and IT Service Management (CITSM), pp. 1-6. IEEE, 2017.

[9] Maucieri, Carmelo, Carlo Nicoletto, Ranka Junge, Zala Schmautz, Paolo Sambo, and Maurizio Borin. "Hydroponic systems and water management in aquaponics: a review." Italian Journal of Agronomy 13, no. 1 (2018): 1-11

[10] Saputra, Randy Erfa, Budhi Irawan, and Yakub Eka Nugraha. "System design and implementation automation system of expert system on hydroponics nutrients control using forward chaining method." In 2017 IEEE Asia Pacific Conference on Wireless and Mobile (APWiMob), pp. 41-46. IEEE, 2017.

[11] Nalwade, Rahul, and Tushar Mote. "Hydroponics farming." In 2017 International Conference on Trends in Electronics and Informatics (ICEI), pp. 645-650. IEEE, 2017.

[12] Sihombing, P., N. A. Karina, J. T. Tarigan, and M. I. Syarif. "Automated hydroponics nutrition plants systems using arduino uno microcontroller based on android." In Journal of Physics: Conference Series, vol. 978, no. 1, p. 012014. IOP Publishing, 2018.

[13] Jun, Ha Joon, Mi Soon Byun, Shi Sheng Liu, Eui Hwan Jeon, and Yong Beom Lee. "Effect of Nutrient Solution Strength on Growth, Fruit Quality and Yield of Strawberry'Mehyang'in Hydroponics." Horticultural Science \& Technology 31, no. 2 (2013): 173-178.

[14] Khan, Fraz Ahmad Ahmad. "A review on hydroponic greenhouse cultivation for sustainable agriculture." International Journal of Agriculture Environment and Food Sciences 2, no. 2 (2018): 59-66.

[15] Ntinas, Georgios K., Kalliopi Kadoglidou, Nektaria Tsivelika, Konstantinos Krommydas, Apostolos Kalivas, Parthenopi Ralli, and Maria Irakli. "Performance and hydroponic tomato crop quality characteristics in a novel greenhouse using dye-sensitized solar cell technology for covering material." Horticulturae 5, no. 2 (2019): 42.

[16] Pardossi, Alberto, Franco Tognoni, and Luca Incrocci. "Mediterranean greenhouse technology." Chronica horticulturae 44, no. 2 (2004): 28-34.

[17] Magwaza, Shirly Tentile, Lembe Samukelo Magwaza, Alfred Oduor Odindo, and Asanda Mditshwa. "Hydroponic technology as decentralised system for domestic wastewater treatment and vegetable production in urban agriculture: A review." Science of the Total Environment 698 (2020): 134154

[18] Crisnapati, Padma Nyoman, I. Nyoman Kusuma Wardana, I. Komang Agus Ady Aryanto, and Agus Hermawan. "Hommons: Hydroponic management and monitoring system for an IOT based NFT farm using web technology." In 2017 5th International Conference on Cyber and IT Service Management (CITSM), pp. 1-6. IEEE, 2017. 